\title{
Relationship between carbon catabolite repression and the biosynthesis regulation of the prolidase PepQ from Lactobacillus delbrueckii ssp. bulgaricus CNRZ 397
}

\author{
Mauld LAMARQUE ${ }^{\mathrm{a}}$, Fabienne MOREL ${ }^{\mathrm{a} *}$, Isabelle BISSARDON ${ }^{\mathrm{a}}$, \\ Anne GALINIER ${ }^{\mathrm{b}}$, Raymond PorTALIER ${ }^{\mathrm{a}}$, Danièle ATLAN ${ }^{\mathrm{a} * *}$ \\ a Unité de Microbiologie et Génétique (UMR CNRS 5577), Université Lyon I, \\ 69622 Villeurbanne Cedex, France \\ ${ }^{\mathrm{b}}$ Institut de Biologie et Chimie des Protéines, UPR CNRS 412, 69367 Lyon Cedex 04, France
}

\begin{abstract}
Lactobacillus delbrueckii ssp. bulgaricus CNRZ 397 (L. bulgaricus) displays several enzymes specific of proline-containing peptides. We focused on the prolidase PepQ which specifically cleaves X-Pro dipeptides. PepQ biosynthesis was previously shown to be independent of the peptide concentration of the culture medium in contrast to the cell surface proteinase PrtB and several aminopeptidases. Regulation of PepQ biosynthesis can be explained by the genetic organization of the region $p e p R 1$-cre-pep $Q$. The $p e p R 1$ gene encodes a CcpA-like regulator and its promoter harbors a cre site located immediately upstream of pepQ. Expression of fusions cre-pepQ-lacZ and pepQ-lacZ in Bacillus subtilis showed that, under glucose conditions, the regulator CcpA acts as a transcriptional activator of pep $Q$ expression. Analysis of PepQ biosynthesis in L. bulgaricus cells grown in different media is in agreement with a regulation dependent on carbohydrates.
\end{abstract}

Lactobacillus delbrueckii ssp. bulgaricus / catabolite repression / PepQ / PepR1

Résumé - Relation entre la répression catabolique et la régulation de la biosynthèse de la prolidase PepQ de Lactobacillus delbrueckii ssp. bulgaricus CNRZ 397. L. bulgaricus synthétise plusieurs enzymes spécifiques des peptides contenant de la proline, dont la prolidase PepQ qui hydrolyse spécifiquement les dipeptides de type X-Pro. Nous avions précédemment montré que, contrairement à certaines aminopeptidases et à la protéinase de surface PrtB, la biosynthèse de PepQ ne dépend pas de la concentration en peptides du milieu de culture. La régulation de la biosynthèse de PepQ peut s'expliquer par l'organisation génétique de la région pepRl-cre-pepQ. Le gène pepRI code pour une protéine de type CcpA et renferme une séquence cible cre qui se situe juste en amont du promoteur du gène $p e p Q$. L'expression de fusions cre-pepQ-lacZ et $p e p Q$-lacZ chez Bacillus

\footnotetext{
* Present address: Université de Bourgogne-ENSBANA, 21000 Dijon, France.

** Correspondence and reprints

Tel.: (33) 4724313 66; fax: (33) 47243 19 71; e-mail: atlan @ biomserv.univ-lyon1.fr
} 
subtilis a montré que, en présence de glucose, CcpA jouait un rôle d'activation de la transcription du gène $p e p Q$. L'analyse de la biosynthèse de PepQ chez $L$. bulgaricus dans différentes conditions de culture est en accord avec une régulation dépendante des carbohydrates.

Lactobacillus delbrueckii ssp. bulgaricus / répression catabolique / PepQ / PepR1

\section{INTRODUCTION}

Lactobacillus delbrueckii ssp. bulgaricus CNRZ 397 (L. bulgaricus) is a thermophilic lactic acid bacterium widely used in fermented milk. Its growth in milk requires a complex proteolytic system which hydrolyzes the major milk proteins (proline-rich caseins) and which provides cells with essential amino acids. First of all, caseins are degraded by a cell surface endoprotease, PrtB [7]. Then, the resulting peptides containing proline are hydrolyzed by several specific peptidases that probably constitute two catabolic pathways leading to the release of the proline residue, essential to L. bulgaricus. One pathway involves an X-prolyl dipeptidyl aminopeptidase (EC 3.4.14.5, PepX) which catalyzes the release of X-Pro dipeptides from oligopeptides with a proline at a penultimate position [2]. X-Pro can be further hydrolyzed by a specific dipeptidase (EC 3.4.13.9, PepQ) [18]. An aminopeptidase P (PepP) and a prolyl aminopeptidase (PepI) are the components of the second pathway [3].

In contrast to lactococci and numerous lactobacilli, PepX and PepI activities of L. bulgaricus are constitutive. Surprisingly, the level of PepQ activity is dependent on the composition of the culture medium, but not on the peptide concentration [18]. A possible regulation mechanism may involve a well-conserved cre sequence ("catabolite responsive element") located immediately upstream of the $p e p Q$ promoter (25 nucleotides) and included in the promoter region of pepRl gene. The PepR1-deduced amino acid sequence is significantly identical $(44 \%)$ to the regulatory CcpA protein ("carbon catabolite protein") that, in the presence of glucose, represses the expression of catabolic operons of Gram-positive bacteria (for a review see [19]). A serylphosphorylated Hpr and CcpA are able to form a complex that enables CcpA to bind a cre sequence.

In this paper, we investigate the regulation mechanism of PepQ biosynthesis via two approaches. On one hand, expression of pepQ-lacZ fusions in Bacillus subtilis pointed out the role of CcpA and its cre target in a regulatory mechanism dependent on glucose conditions. On the other hand, we followed PepQ biosynthesis in L. bulgaricus by western blot analysis and confirmed its dependence on the composition of the culture medium.

\section{MATERIALS AND METHODS}

\subsection{Bacterial strains and culture conditions}

Bacterial strains and plasmids used in this study are listed in Table I. Escherichia coli was grown aerobically at $37{ }^{\circ} \mathrm{C}$ in LB medium [16]. Bacillus subtilis was cultivated in LB medium or minimal medium (CSK) supplemented or not with $1 \%$ glucose [15]. L. bulgaricus was grown anaerobically at $40{ }^{\circ} \mathrm{C}$ in MRS [6] or reconstituted Gamma milk (10\%) as previously described [18]. When required, the medium was supplemented with ampicillin $\left(100 \mu \mathrm{g} \cdot \mathrm{mL}^{-1}\right)$, kanamycin $\left(5 \mu \mathrm{g} \cdot \mathrm{mL}^{-1}\right)$ or erythromycin $\left(5 \mu \mathrm{g} \cdot \mathrm{mL}^{-1}\right)$. 
Table 1. Bacterial strains and plasmids.

\begin{tabular}{|c|c|c|}
\hline Strain or plasmid & Genotype or relevant characteristic & Reference or source \\
\hline \multicolumn{3}{|l|}{ Escherichia coli } \\
\hline NM 522 & $\mathrm{~F}^{\prime}$ lacI ${ }^{q} \Delta\left(\right.$ lacZ)M15 $\mathrm{proA}^{+} B^{+} / \operatorname{supE}$ thi $\Delta($ lac-proAB $)$ & \\
\hline & $\Delta(h s d M S-m c r B) 5\left(\mathrm{r}_{\mathrm{k}}^{-}, \mathrm{m}_{\mathrm{k}}^{-} \mathrm{McrBC}^{-}\right)$ & \\
\hline FM9003 & $\mathrm{RecA}^{-}$and $\mathrm{PepP}^{-}$derivative of $\mathrm{CM} 90$ & {$[18]$} \\
\hline \multicolumn{3}{|l|}{ Bacillus subtilis } \\
\hline 168 & $\operatorname{trp} C$ & Institut Pasteur, Paris \\
\hline FMML & 168 derivative, amyE:: ('lacZ), $\mathrm{Kn}^{\mathrm{R}}$ & this work \\
\hline FMML1 & 168 derivative, amyE::(cre-pepQ'-'lacZ), $\mathrm{Kn}^{\mathrm{R}}$ & this work \\
\hline FMML2 & 168 derivative, amyE::(pepQ'-'lacZ), $\mathrm{Kn}^{\mathrm{R}}$ & this work \\
\hline \multicolumn{3}{|l|}{ Lactobacillus delbrueckii } \\
\hline ssp. bulgaricus CNRZ 397 & & {$[18]$} \\
\hline \multicolumn{3}{|l|}{ Plasmid } \\
\hline $\mathrm{pAC7}$ & $10.6 \mathrm{~kb}, \mathrm{Ap}^{\mathrm{R}}, \mathrm{Kn}^{\mathrm{R}}$, promoterless lacZ, amyE'-'amyE & {$[24]$} \\
\hline pAQ1 & pAC7 derivative, amyE::(cre-pep $Q^{\prime}$-'lacZ) & this work \\
\hline pAQ2 & pAC7 derivative, amyE::(pepQ' -'lacZ) & this work \\
\hline pQBB12 & pLG339 derivative containing promoter and pep $Q$ gene & {$[18]$} \\
\hline
\end{tabular}

\subsection{Preparations of cell extracts}

Bacterial cultures were grown in $50 \mathrm{~mL}$ medium and collected at $\mathrm{A}_{600 \mathrm{~nm}} 0.8-1.0$ (or as indicated), by centrifugation (12 $000 \mathrm{~g}$, $10 \mathrm{~min}, 4^{\circ} \mathrm{C}$ ). After washing with $10 \mathrm{~mL}$ of $200 \mathrm{mmol} \cdot \mathrm{L}^{-1}$ Tris/ $\mathrm{HCl} \mathrm{pH} 7.0$, bacterial cells were broken with a French Press (20 000 psi) and unbroken cells removed by centrifugation $\left(20000 \mathrm{~g}, 20 \mathrm{~min}, 4^{\circ} \mathrm{C}\right)$.

\subsection{Protein and $\beta$-galactosidase assay}

Protein concentration was determined by the Bradford method [5] with bovine serum albumin as a standard. $\beta$-galactosidase activity was assayed by the Miller method [16]. One unit of $\beta$-galactosidase activity is defined as the amount of enzyme that produces $1 \mu \mathrm{mol}$ of $o$-nitrophenol per min at $37^{\circ} \mathrm{C}$.

\section{4. $\alpha$-amylase activity in situ test}

Bacterial colonies were grown overnight on LB medium supplemented with $50 \mathrm{~g} \cdot \mathrm{L}^{-1}$ agar and $50 \mathrm{~g} \cdot \mathrm{L}^{-1}$ starch. The addition of a $3 \mathrm{mmol} \cdot \mathrm{L}^{-1} \mathrm{I}_{2}$ and $125 \mathrm{mmol} \cdot \mathrm{L}^{-1} \mathrm{KI}$ solution turns the starch to a violet background. Colonies secreting $\alpha$-amylase are surrounded by a clear halo.

\subsection{DNA procedures}

Plasmid extraction and E. coli transformation were carried out as described by Sambrook et al. [20]. Spontaneous competence of B. subtilis was used for transformation as described by Kunst and Rapoport [11]. PCR was performed with the Advantage $^{\mathrm{TM}}$ Genomic PCR kit (Clontech, Palo Alto, CA, USA) and primers were provided by Life Technologies-Gibco-BRL (CergyPontoise, France). DNA fragments were 
(A)

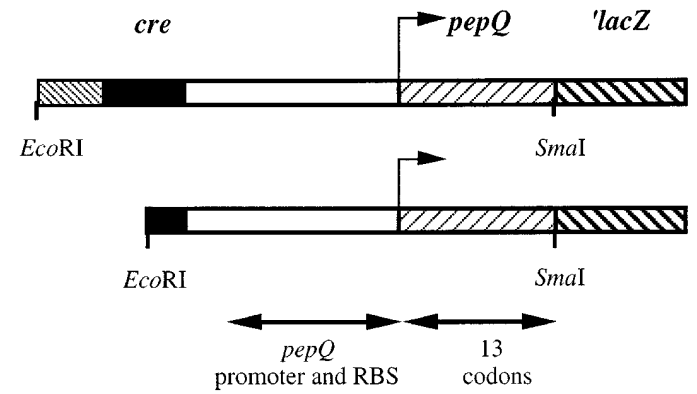

Figure 1. Fusions cre-pepQ-lacZ (A) and pepQ-lacZ (B).

purified with the UltraClean Gen-apex DNA purification kit (Prolabo-Merck Eurolab, Fontenay-sous-Bois, France). DNA sequencing was performed using the T7-sequencing kit (Amersham Pharmacia Biotech, Saclay, France).

\subsection{Western blotting and immunodetection}

Cell extracts equivalent to $7 \mu \mathrm{g}$ of bacterial proteins were boiled for $4 \mathrm{~min}$ in the presence of $0.1 \% \mathrm{SDS}$ and $0.1 \mathrm{~mol} \cdot \mathrm{L}^{-1}$ $\beta$-mercaptoethanol. Bacterial proteins were separated by SDS-PAGE [12] and electrotransferred to a nitrocellulose membrane (Schleicher \& Schuell, Ecquevilly, France). Immunoblots were carried out by the Harlow and Lane method [10] using anti-PepQ antibodies and anti-rabbit IgG peroxidase conjugate (Sigma-Aldrich, L'isle-d'Abeau Chesnes, France) revealed by a chemiluminescent substrate (BM Chemiluminescence Western Blotting Substrate, Roche Molecular Biochemicals, Meylan, France). Each sample was tested at least three times.

\section{RESULTS AND DISCUSSION}

\subsection{Construction of fusions between pep $Q$ and 'lacZ genes}

In order to determine if the cre site located upstream of the $\operatorname{pep} Q$ promoter is involved in the pep $Q$ expression, we con- structed two fusions between $p e p Q$ and the reporter lacZ gene, devoid of its own promoter. Two fragments were amplified by PCR introducing EcoRI and SmaI restriction sites at the 5' and 3' ends, respectively. The fragment A (Fig. 1), containing the cre sequence and the adjacent $p e p Q$ and $p e p R I$ promoters, was obtained with the primers Q2 (5'-CTAATTACTGAATTCATGATACCATGA-3') and Q1 (5'-GTCCATCCCGGGTTCCTGCAGCC-3') (restriction sites are underlined). PCR with the primers Q3 (5'-GGTGCAATCGAATTCAGCTATTTTTTC-3') and Q1 allowed the amplification of the fragment $\mathrm{B}$ with a truncated cre site. These PCR fragments were cloned between the EcoRI and SmaI sites of plasmid pAC7 (Fig. 2). The resulting plasmids pAQ1 and pAQ2, harboring crepepQ-lac $Z$ and pep $Q$-lac $Z$ fusions, respectively, were used to transform $E$. coli NM522. The $A p^{R}$ transformants obtained

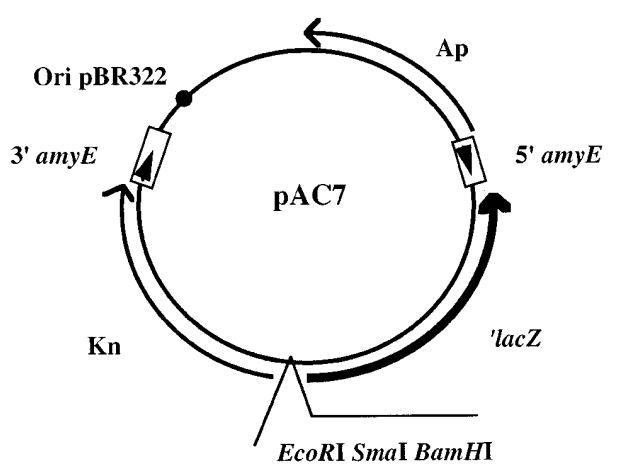

Figure 2. Plasmid pAC7 [24]. 
with $\mathrm{pAQ} 1$ or $\mathrm{pAQ} 2$ were able to degrade the chromogen substrate X-Gal (5-bromo-4chloro-3-indolyl- $\beta$-D-galactopyranoside) in contrast to transformants harboring pAC7. This reflects the presence of a $\beta$-galactosidase activity expressed from cre-pepQ-lac $Z$ and $p e p Q$-lacZ fusions, whose nucleotide sequences were controlled by sequencing. Then, B. subtilis 168 was transformed with pAC7, pAQ1 and pAQ2, resulting in strains FMML, FMML1 and FMML2, respectively, with $K n$-lacZ regions inserted at the chromosomal amyE locus. The three strains are resistant to kanamycin and deficient in $\alpha$-amylase activity, as shown by an in situ enzymatic test. The presence of chromosomal fusions were also controlled by Southern blot experiments with an appropriate probe labeled with digoxigenin (data not shown).

\subsection{Effect of the cre site on the expression of pepQ-lacZ fusions in B. subtilis}

Strains FMML, FMML1 and FMML2

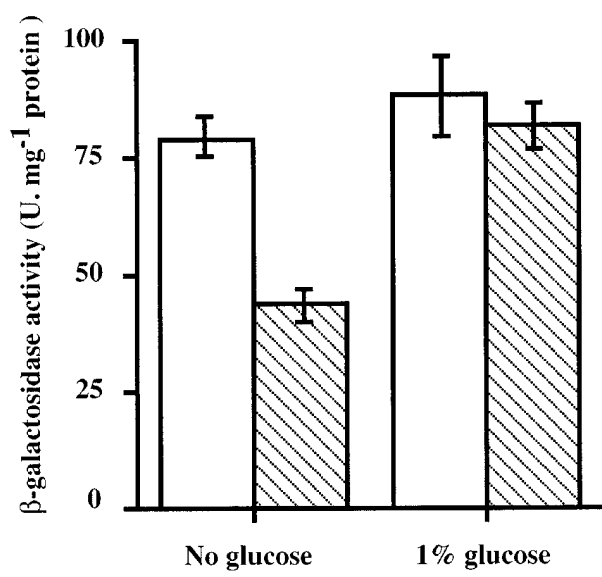

Figure 3. $\beta$-galactosidase activities assayed in cellular extracts from exponential- or stationaryphase cultures of strains FMML1 (hatched bars) and FMML2 (blank bars) grown in LB medium with or without glucose. Enzyme activities were calculated from three independent experiments. were cultivated in LB medium supplemented, or not, with $1 \%$ glucose. No significant $\beta$-galactosidase activity was detected in cell extracts from FMML (data not shown). The presence of glucose does not significantly affect the $\beta$-galactosidase activity of strain FMML2 (Fig. 3). By contrast, the strain FMML1 displays a two-fold higher $\beta$-galactosidase activity, after cellular growth with glucose. This data suggests that, in vivo and under glucose conditions, the cre site upstream of the pepQ-lacZ fusion is recognized by the $C \mathrm{cpA}$ regulator from $B$. subtilis and results in an activation of the fusion expression.

The comparison of strains FMML1 and FMML2 points out that, in the absence of glucose, the presence of the cre site is correlated to a lower expression of the fusion.

\subsection{PepQ biosynthesis in L. bulgaricus CNRZ 397}

PepQ biosynthesis was followed in L. bulgaricus cells during growth in MRS medium (rich in dextrose, i.e. glucose) or milk (rich in lactose). Western blot analysis of cell extracts from L. bulgaricus (Fig. 4) was performed with antibodies raised against the purified PepQ protein from L. bulgaricus CNRZ 397 [18]. The major band (48 $\left.\mathrm{kg} \cdot \mathrm{mol}^{-1}\right)$ corresponds to PepQ: its concentration is slightly higher in extracts obtained from MRS cultures than those from milk (at an equivalent step of growth) (Fig. 4A). The ratio of PepQ to total cellular proteins does seem modified during the exponential phase in MRS medium (Figs. 4A and 4B). Taken together, these results support the hypothesis that a factor of MRS medium could induce an activation mechanism of the PepQ biosynthesis. Previous results have shown that the addition of peptides from a casein hydrolysate has no effect on the PepQ biosynthesis [18]. Therefore, the presence of D-glucose (dextrose) could be a factor implied in the regulation mechanism. 


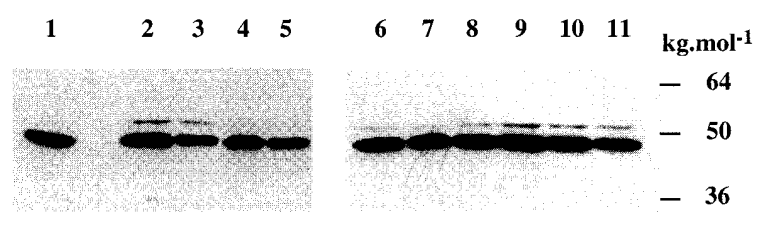

Figure 4. PepQ immunodetection from total cellular extracts after SDS-PAGE (A) and growth kinetics of L. delbrueckii ssp. bulgaricus in MRS medium (B). Lane 1: E. coli strain harboring pQBB12 plasmid; lane 2 to 11 : L. delbrueckii ssp. bulgaricus after growth in milk (lanes 3 and 5: $\mathrm{A}_{600} 0.7$ and 1.0 , respectively) or in MRS (the lanes 2 and 4 are identical to lanes 6 and 7: $\mathrm{A}_{600}$ 0.8 and 1.0 , respectively; lanes 8 to 11: $\mathrm{A}_{600} 2.0,4.2,6.0$ and 7.0, respectively). Western blots of each sample were repeated at least three times.

\section{CONCLUSION}

In L. delbrueckii ssp. bulgaricus, the genetic organization pepRl (or ccpA homologous)-pep $Q$ is identical to that found in Streptococcus mutans (regM ) [23] and several lactic acid bacteria: L. delbrueckii ssp. lactis (pepR1) [21], L. pentosus [14], L. casei [17] and Lactococcus lactis [4]. Surprisingly, the PepQ biosynthesis appears differently regulated among these strains. In Streptococcus mutans, PepQ biosynthesis is shown to be constitutive [23]. By contrast, PepQ activity in $L$. delbrueckii ssp. lactis was shown to be 1.7 to 2.0 -fold higher in cells grown in the presence of glucose compared to a culture with lactose [21].

Our results showed that the presence of the cre site upstream of the $p e p Q$ promoter leads to a regulation mechanism of pep $Q$ transcription mediated by carbon catabolite repression. Actually, under catabolite repression conditions (presence of glucose in the culture medium), the complex CcpA-HPr P of $B$. subtilis appears to be able to bind the cre target and this results in an activation of the pep $Q$ promoter. The activator function of CcpA has already been pointed out for two genes of $B$. subtilis encoding acetate kinase or phosphotransacetylase [9, 22]. A two-fold increase of pyruvate kinase and lactate deshydrogenase activities of Lactococcus lactis has also been observed under glucose conditions [13]. The genes encoding these enzymes belong to the las operon, the transcription of which is activated by the binding of CcpA to a cre site located immediately upstream of the -35 box of the las promoter. It is tempting to speculate that in L. bulgaricus cells, the higher amount of PepQ protein obtained in MRS culture could be the result of a transcriptional activation involving the CcpA-like regulator, PepR1. The analysis of the regulation of PepR 1 biosynthesis is in process.

The proteolytic system of L. bulgaricus is not submitted to a single global regulation but depends on different signals. Actually, biosynthesis of some proteolytic enzymes are constitutive (PepN, PepX, PepIP) or dependent on the concentration of peptides (PrtB, Aminopeptidases I and III) or glucose (PepQ) [1,8].

\section{ACKNOWLEDGEMENTS}

This work was supported by research grants from the Centre National de la Recherche Scientifique (UMR CNRS 5577) and the University Claude Bernard-Lyon I. 


\section{REFERENCES}

[1] Atlan D., Laloi P., Portalier R., Isolation and characterization of aminopeptidase-deficient Lactobacillus bulgaricus mutants, Appl. Environ. Microbiol. 55 (1989) 1717-1723.

[2] Atlan D., Laloi P., Portalier R., X-proline-dipeptidyl-aminopeptidase of Lactobacillus del brueckii subsp. bulgaricus: characterization of the enzyme and isolation of deficient mutants, Appl. Environ. Microbiol. 56 (1990) 2174-2179.

[3] Atlan D., Gilbert C., Blanc B., Portalier R., Cloning, sequencing and characterization of the pepIP gene encoding a proline iminopeptidase from Lactobacillus delbrueckii subsp. bulgaricus CNRZ 397, Microbiology 140 (1994) 527-535.

[4] Bolotin A., Mauger S., Malarme K., Ehrlich S., Sorokin A., Low-redundancy sequencing of the entire Lactococcus lactis IL1403 genome, Antonie van Leeuwenhoek 76 (1995) 27-76.

[5] Bradford M., A rapid and sensitive method for the quantitation of microgram quantities of protein utilizing the principle of protein-dye binding, Anal. Biochem. 72 (1976) 248-254.

[6] deMan J., Rogosa M., Sharpe E., A medium for the cultivation of lactobacilli, J. Appl. Bacteriol. 23 (1960) 130-135.

[7] Gilbert C., Atlan D., Blanc B., Portalier R., Germond J.-E., Lapierre L., Mollet B., A new cell surface proteinase: sequencing and analysis of the prtB gene from Lactobacillus delbrueckii subsp. bulgaricus, J. Bacteriol. 178 (1996) 3059-3065.

[8] Gilbert C., Blanc B., Frot-Coutaz J., Portalier R., Atlan D., Comparison of cell surface proteinase activities in Lactobacillus genus, J. Dairy Res. 64 (1997) 561-571.

[9] Grundy F., Waters D., Allen S., Henkin T., Regulation of the acetate kinase gene by CcpA, J. Bacteriol. 175 (1993) 7348-7355.

[10] Harlow E., Lane D., Antibodies. A laboratory manual, Cold Spring Harbor, Cold Spring Harbor Laboratory, New York, USA, 1988.

[11] Kunst F., Rapoport G., Salt stress is an environmental signal affecting degradative enzyme synthesis in Bacillus subtilis, J. Bacteriol. 177 (1995) 2403-2407.

[12] Laemmli U., Cleavage of structural proteins during assembly of the head of the bacteriophage T4, Nature 277 (1970) 680-685.
[13] Luesink E., van Herpen R., Grossiord B., Kuipers O., de Vos W., Transcriptional activation of the glycolytic las operon and catabolite repression of the gal in Lactococcus lactis are mediated by the catabolite control protein CcpA, Mol. Microbiol. 30 (1998) 789-798.

[14] Mahr K., Hillen W., Titgemeyer F., Carbon catabolite repression in Lactobacillus pentosus: Analysis of the ccpA region, Appl. Environ. Microbiol. 66 (2000) 277-283.

[15] Martin-Verstraete I., Débarbouillé M., Klier A. Rapoport G., Levanase operon of Bacillus subtilis includes a fructose-specific phosphotransferase system regulating the expression of the operon, J. Mol. Biol. 214 (1990) 657-671.

[16] Miller J., Experiments in Molecular Genetics, Cold Spring Harbor, Cold Spring Harbor Laboratory, New York, USA, 1972.

[17] Monedero V., Gosalbes M., Perez-Martinez G. Catabolite repression in Lactobacillus casei ATCC393 is mediated by CcpA, J. Bacteriol. 179 (1997) 6657-6664.

[18] Morel F., Frot-Coutaz J., Aubel D., Portalier R. Atlan D., Characterization of a prolidase from Lactobacillus delbrueckii subsp. bulgaricus CNRZ 397 with an unusual regulation of biosynthesis, Microbiology 145 (1999) 437-446.

[19] Saier M., Chauvaux S., Cook G., Deutscher J., Paulsen I., Reizer J., Ye J., Catabolite repression and inducer control in Gram-positive bacteria, Microbiology 142 (1996) 217-230.

[20] Sambrook J., Fritsch E., Maniatis T., Molecular Cloning: a Laboratory Manual (2nd ed.), Cold Spring Harbor Laboratory, Cold Spring Harbor, New York, USA, 1989.

[21] Schick J., Weber B., Klein J., Henrich B. PepR1, a CcpA-like transcription regulator of Lactobacillus delbrueckii subsp. lactis, Microbiology 145 (1999) 3147-3154.

[22] Shin B., Choi S., Park H., Regulation of the Bacillus subtilis phosphotransacetylase gene, J. Biochem. 126 (1999) 333-339.

[23] Simpson C., Russel R., Identification of a homologue of CcpA catabolite repressor protein in Streptococcus mutans, Infect. Immun. 66 (1998) 2085-2092.

[24] Weinrauch Y., Msadek T., Kunst F., Dubnau D., Sequence and properties of $\operatorname{com} Q$, a new competence regulatory gene of Bacillus subtilis, J. Bacteriol. 173 (1991) 5685-5693. 